\title{
DHABITH KRITERIA HADIS SHAHIH Studi Kasus: Periwayatan Hadis bi al-Ma'na
}

\author{
Sri Chalida \\ UIN Imam Bonjol Padang \\ srichalida@uinib.ac.id
}

\begin{abstract}
Abstrak. Dhabith Kriteria Hadis Shahih. Hadis Rasulullah SAW dalam bentuk qauli (perkataan) dapat diriwayatkan dengan bentuk lafaz sesuai dengan apa yang disampaikan oleh Rasulullah, namun hadis dalam bentuk perbuatan dan taqrir beliau, sudah tentu diformulasikan oleh para sahabat yang menyaksikannya. Kenyataannya tidak semua hadis qauli ini disampaikan dengan lafaz yang sama. Ada kalanya memang Rasulullah SAW sendiri yang menyampaikan lafaz yang berbeda karena para shahabat yang menerimanya tidak paham dengan lafaz yang pertama disampaikan Rasulullah SAW, sehingga Rasulullah SAW menggantinya dengan lafaz lain yang dimengerti oleh para shahabat tersebut. Namun ada kalanya para periwayat hadis mengganti lafaz hadis tersebut dengan kata yang bersinonim disebabkan mereka tidak dapat mengingat lafaz asli yang didengarnya dari Rasulullah SAW. Pada hal dalam menyampaikan hadis, para periwayat tersebut harus dhabith atau dapat menerima hadis dengan baik dan benar dan menyampaikannya kembali sebagaimana yang diterimanya dengan baik dan benar pula.Periwatan hadis yang tidak sesuai dengan lafaz aslinya ini disebut riwayat bi alma'na. Dalam realitasnya periwayatan hadis bi al-ma'na ini tidak dapat dihindari dan sering terjadi. Dalam sejarah hadis, pada awalnya ternyata periwayatan hadis $b i$ al-ma'na ini merupakan dispensasi sebelum kitab-kitab hadis dibukukan. Dispensasi bagi periwayatan bi al-ma'na ini bukanlah merupakan indikasi dari ketidakkonsistenan para ulama dalam memenuhi persyaratan ke-dhabith-an, karena sebenarnya para ulama telah menetapkan kriteria-kriteria tertentu yang harus dipenuhi para rawi dalam periwayatan hadis .
\end{abstract}

Kata Kunci : Hadits, Dhabith, Periwayatan bi al-ma'na,

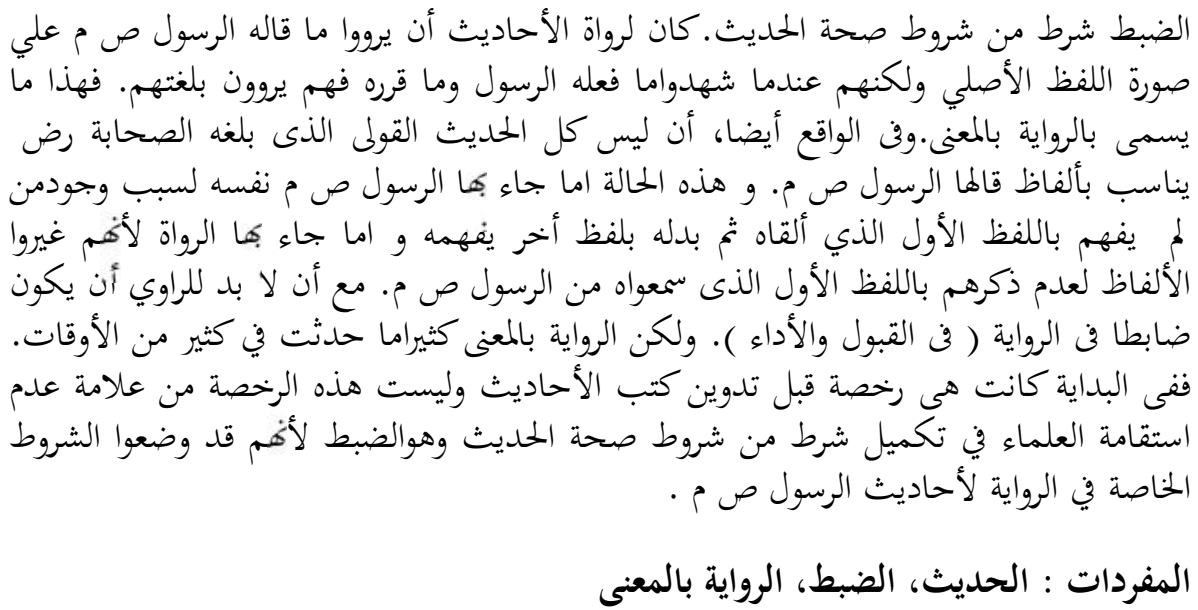




\section{PENDAHULUAN}

Hadis sebagai perkataan, perbuatan, taqrir dan hal ihwal Nabi Muhammad SAW, ${ }^{1}$ mempunyai nilai tinggi sesudah Al-Quran. Ayat-ayat AlQuran banyak yang dikemukakan secara umum dan memerlukan perincian dari hadis Rasulullah SAW agar dapat dimengerti, dipahami dan diamalkan dalam kehidupan sehari-hari. Al-Quran dan hadis merupakan dua pedoman yang tidak dapat dipisahkan satu sama lain.

Di dalam Al-Quran banyak kita temui ayat-ayat yang menyatakan wajib mengikuti hadis Rasulullah SAW, antara lain berbunyi:

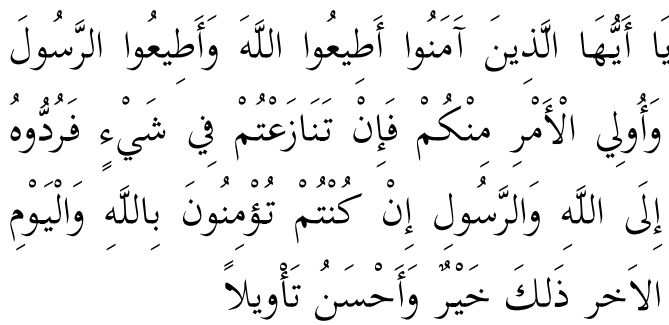

Hai orang-orang yang beriman, taatilah Allah dan taatilah Rasul (nya), dan ulil amri di antara kamu. Kemudian jika kamu berlainan pendapat tentang sesuatu, maka kembalikanlah ia kepada Allah (Al Quran) dan Rasul (sunnahnya), jika kamu benar-benar beriman kepada Allah dan hari kemudian. yang demikian itu lebih utama (bagimu) dan lebih baik akibatnya.

${ }^{1}$ Definisi hadis manurut para ulama hadis, lebih lanjut lihat: Nur al-Din ' Itr, Manhaj al-Naqd fiy ' Ulum al-Hadis, (Damsyiq: Dar al-Fikr, 1399 H / 1979 M), Cet. -2 , h. 26
Mengingat pentingnya kedudukan hadis dalam syari'at Islam dan fungsinya terhadapnya Al-Qur'an, para sahabat memberikan perhatian yang besar terhadap hadis Nabi Muhammad SAW dan berusaha keras untuk memperolehnya sebagaimana perhatian mereka terhadap Al-Quran. Mereka menghafal lafaz-lafaz hadis sebaik mungkin atau paling tidak maknanya, memahami dan mengetahui maksud tujuannya dengan berdasarkan pengetahuan mereka mengenai situasi dan kondisi yang melatar belakangi timbulnya hadis tersebut. Hadis-hadis yang sulit diketahui dan dipahami maksud dan tujuannya mereka tanyakan langsung kepada Nabi Muhammad SAW.

Perhatian dan kesungguhan para sahabat terhadap hadis Nabi Muhammad SAW, terbukti bahwa di antara mereka ada yang bergantian mendatangi Nabi Muhammad SAW, sebagaimana yang dilakukan Umar Ibn al-Khaththab dengan tetangganya seorang Anshar sebagai berikut:

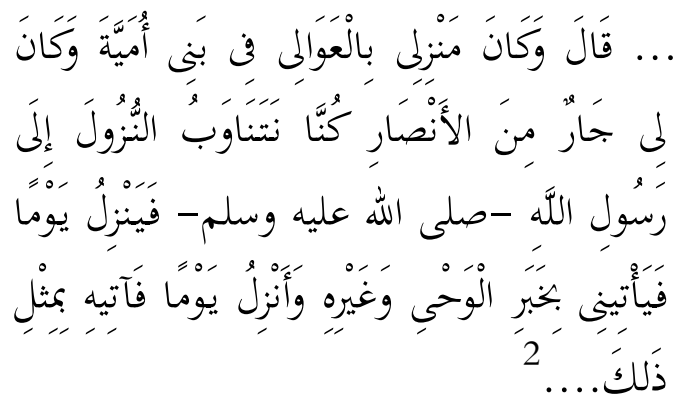

${ }^{2}$ Abu Isa Muhammad Ibn Isa Ibn Surah al-Tirmidziy, (selanjutnya disebut Imam al-Tirmidzi) Sunan al-Tirmidziy wa Huwa alJami' al-Shahih, (Beirut: Dar al-Kutub alIlmiyah, 2006), h. 765 
... Aku tinggal di kalangan Bani Umayyah dan aku bertetangga dengan kaum Anshar, kami silih berganti mengunjungi Rasulullah SAW. Tatkala tetanggaku yang mengunjungi Rasulullah SAW lalu ia menemuiku untuk menyampaikan wahyu atau hadis yang diterimanya dari Rasulullah SAW, hari berikutnya aku yang mengunjungi Rasulullah SAW, maka aku pun menyampaikan kepada tetanggaku itu apa yang aku dapat dari Rasulullah SAW, seperti inilah berikutnya.

"Dengan bergiliran mendatangi Rasulullah SAW', berat dugaan bahwa sebahagian besar dari hadishadis Rasulullah SAW diterima dan dihafal oleh para sahabat. Kebijaksanaan para sahabat ini sesuai dengan sabda Rasulullah SAW:

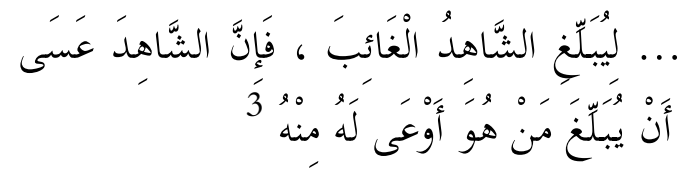

... Hendaklah orang yang hadir menyampaikan kepada yang tidak hadir. Karena sesungguhnya orang yang hadir boleh jadi menyampaikan kepada orang yang lebih paham daripadanya terhadap apa yang disampaikannya itu.

Pada masa Nabi Muhammad SAW masih hidup, telah ada sebahagian sahabat yang menulis hadis, tetapi jumlah mereka sangat sedikit dan jumlah hadis-hadis yang mereka catat juga sangat terbatas. Hal ini terjadi karena para sahabat saat itu sangat sedikit sekali jumlahnya yang pandai

3 Abu 'Abd Allah Muhammad Ibn Ismail al-Bukhariy, selanjutnya disebut Imam al-Bukhariy, Al-Jami'al-Shahih (Shahih alBukhariy), (Beirut:Dar al-Fikr, / t. th.), juz.1, h. 26 tulis baca, lagi pula perhatian mereka terfokus terhadap pemeliharaan $\mathrm{Al}$ quran. Sebelum hadis-hadis tersebut dihimpun dan dibukukan secara resmi, hadis-hadis Nabi Muhammad SAW tersebut diajarkan dan diriwayatkan dari mulut ke mulut secara lisan dan hafalan. Hal ini sesuai dengan keadaan masyarakat Arab yang terkenal kuat hafalannya, juga berdasarkan beberapa sabda Rasulullah SAW sendiri yang melarang penulisan hadis tersebut. Salah satu di antaranya:

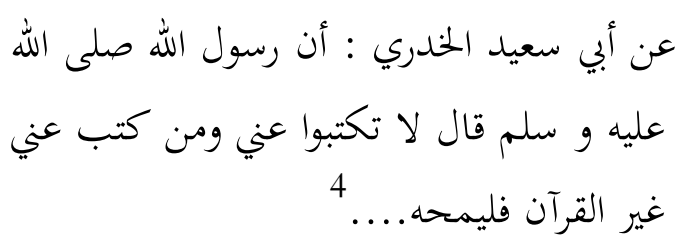

Abu Said al-Khudriy menyampaikan hadis, bahwa Rasulullah SAW bersabda: jangan engkau tulis apa yang engkau dengar dari padaku selain dari Al-Quran. Siapa yang menulis sesuatu selain Al-Quran, hendaklah ia hapus.

Namun bukan berarti ketika itu pencatatan hadis tidak ada sama sekali. Akan tetapi banyak di antara para sahabat yang membuat catatan hadis, hanya saja masih bersifat pribadi dan belum resmi. Hal ini dapat dipahami dengan adanya perintah Rasulullah SAW menuliskan hadis untuk salah seorang sahabat tertentu yang termaktub dalam ungkapan hadis tersebut:

${ }^{4}$ Imam Abu al-Husain Muslim Ibn alHajjaj al-Qusyairiy al-Naisaburiy, selanjutnya disebut Imam Muslim, Shahih Muslim, (Beirut: Dar al-Kutub al-Ilmiyah, 2003), h. 1145 
•.. فقام أبو شاه رجل من أهل اليمن فقال اكتبوا لي يا رسول الله فقال رسول الله صلى الله عليه و سلم اكتبوا لأبي شاه

... Telah berdiri seorang laki-laki penduduk Yaman (ketika itu Nabi baru saja menyampaikan satu hadis ) lalu ia berkata: tuliskanlah untukku ya Rasulullah, lalu Rasulullah SAW bersabda: Tuliskanlah untuk Abu Syah.

Kendatipun begitu, kewajiban seorang periwayat adalah menjelas-kan bentuk-bentuk penerimaan hadis yang diriwayatkannya tanpa melaku-kan penyimpangan dan perubahan. Dengan kata lain periwayat dituntut agar menyampaikan atau meriwa-yatkan suatu hadis persis seperti apa yang didengarnya, sebagaimana yang tercantum dalam sabda Rasulullah:

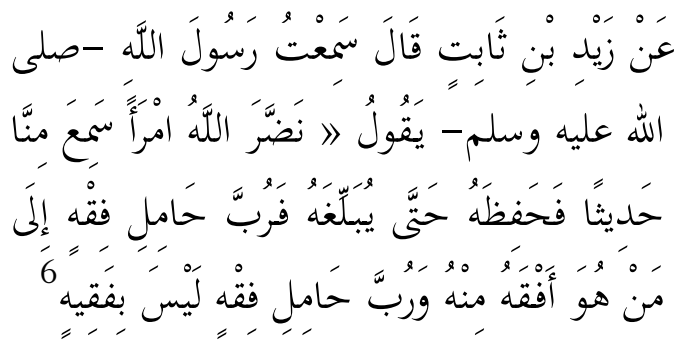

Hadis dari Zaid Ibn Tsabit, ia berkata, aku telah mendengar Rasulullah SAW bersabda: Semoga Allah mencemerlangkan wajah seseorang yang mendengarkan suatu hadis dari kami, lalu dihafalnya hingga ia menyampaikannya. Betapa banyak orang yang menyampaikan hadis kepada orang yang lebih paham

\footnotetext{
${ }^{5}$ Imam al-Bukhariy, op. cit., h. 36

${ }^{6}$ Abu Daud Sulaiman Ibn al-'Asy’as al-Sijistaniy, Sunan Abiy Daud, (Indonesia: Maktabat al-Rihlaniy, /t. th.. )juz . 3 , h.322
}

daripadanya dan betapa banyak pula orang yang menyampaikan hadis ia sendiri tidak memahaminya.

Kenyataannya dalam periwayatan hadis tidaklah demikian halnya, karena tidak semua periwayat mempunyai daya tangkap dan kemampuan yang sama untuk menghafal, memahami dan menyampaikan kembali hadis-hadis yang pernah ia dengar dari guru-gurunya. Karena itu timbullah hadis-hadis tentang suatu topik dengan redaksi yang berbeda-beda namun mengandung makna yang sama yang disebabkan karena periwayat lupa atau tidak ingat lafaz hadis yang pernah disampaikan Rasulullah SAW.

\section{PEMBAHASAN}

Hadis yang dapat diperpegangai adalah hadis shahih yakni sanadnya muttashil, para periwayatnya 'adil lagi dhabith, tidak ada syadz dan illat. $^{7}$

روى adalah masdar dari yang berarti periwayatan. $^{8}$ Menurut ulama hadis yang dimaksud riwayat adalah kegiatan penerimaan dan penyampaian hadis serta menyandarkan hadis tersebut kepada para periwayatnya. ${ }^{9}$ Hadis menurut ulama hadis adalah apa saja yang disandarkan kepada Rasulullah SAW, baik perkataan, perbuatan, taqrir, bentuk fisik, akhlaq dan perjalanan

${ }^{7}$ Abu Daud Sulaiman Ibn al-'Asy’as al-Sijistaniy, Sunan Abiy Daud, (Indonesia: Maktabat al-Rihlaniy, t. th..), juz . 3 , h. 322

${ }^{8}$ Mahmud Yunus, Kamus ArabIndonesia, (Jakarta: Hidakarya Agung, 1990), h. 829

${ }^{9}$ Nur al-Din 'Itr, op. cit., h. 188 
hidup Nabi Muhammad SAW, sebelum atau setelah bi'tsah. ${ }^{10}$ المعنى adalah masdar mimiy dari عنى - عang yang berarti makna atau maksud dari sesuatu. $^{11}$ Periwayatan bi al-ma'na berarti penyampaian hadis-hadis Rasulullah SAW berdasarkan maksud atau makna yang dikandung lafaz, bukan seperti lafaz yang pernah disampaikan Rasulullah SAW.

Hadis-hadis yang dimaksud dalam periwayatan hadis bi al-ma'na ini adalah hadis-hadis qauliy, sedangkan hadis-hadis fi'liy atau taqriry, pastilah berbeda-beda lafaznya sesuai dengan kata-kata yang diformulasikan oleh para shahabat yang menyaksikannya. Hal ini bukan bahasan periwayatan hadis bi al-ma'na.

Dalam periwayatan hadis, para muhaddisin telah menetapkan kriteria suatu hadis yang dapat diterima. Salah satu di antaranya adalah periwayat haruslah seorang yang dhabith, artinya kuat ingatan dan bagus hafalannya. Hal ini dikemukakan Shubhi al-Shalih dalam ungkapan berikut:

والمراد بضبط الراوي سماعه للرواية كما يجب

وفهمه لها فهما دقيقا وحفظه لها حفظا كاملا
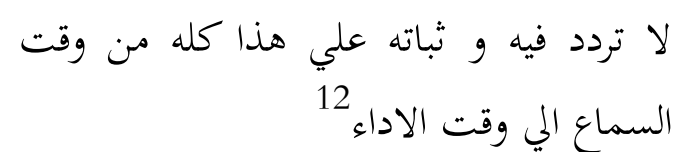

${ }^{10}$ Muhammad 'Ajjaj al-Khatib, Ushul al-Hadis: 'Ulumuh wa Mushthalahuh, (Beirut: Dar al-Fikr, 2008), h. 14

${ }^{11}$ Mahmud Yunus, op. cit., h. 283

${ }^{12}$ Shubhi al-Shalih, 'Ulum al-Hadis wa Mushthalahuh ( Beirut: Dar al-'Ilm li alMalayin , 1977), Cet . -9 , h. 128
Yang dimaksud ke-dhabith-an periwayat adalah periwayat yang pendengarannya terhadap suatu riwayat atau hadis sebagaimana mestinya, pemahamannya terhadap hadis itu mendalam, hafalannya sempurna dan tidak terjadi perubahan dalam hafalannya tersebut, semua ini berlaku dari waktu ia mendengarkan suatu hadis sampai ia meriwayatkan hadis itu kembali.

Fathur Rahman menjelaskan bahwa dhabith adalah: orang yang kuat ingatannya, artinya bahwa ingatnya lebih banyak daripada lupanya dan kebenarannya lebih banyak daripada kesalahannya. Kalau seseorang yang mempunyai ingatan yang kuat sejak dari menerima sampai meriwayatkan hadis kepada orang lain dan ingatannya itu sanggup disampaikannya kapan dan di mana saja dikehendaki atau diminta, disebut orang yang dhabith shadran, kalau apa yang disampaikannya itu berdasarkan catatannya yang rapi, terpelihara dari penambahan dan pengurangan serta ketercampurannya dengan hadis lain atau catatan lainnnya dinamakan orang dhabith al-kitaban. ${ }^{13}$

Berdasarkan ungkapan di atas jelaslah bahwa periwayat yang diterima riwayatnya adalah periwayat yang dhabith, yang berarti mempunyai daya tanggap yang tepat terhadap hadishadis yang didengarnya, pemahamannya mendalam, sempurna hafalannya sehingga ia dapat menyampaikan hadis itu kapan pun diminta dan diperlukan.

\footnotetext{
${ }^{13}$ Fathur Rahman, Ikhtisar Mushthalah
} al-Hadis, (Yogyakarta: PT. Al-Ma'arif, 1985), Cet. $-4, \quad$ h. 99 
Apabila hadis diartikan ucapan, perbuatan dan taqrir Nabi Muhammad SAW, maka dapat dikatakan bahwa tidak mungkin seluruh hadis diriwayatkan secara lafaz dari Nabi SAW. Hanya ucapan beliaulah yang dapat diriwayatkan secara teks murni. Adapun hadi-hadis yang menerangkan perbuatan dan taqrir Nabi Muhammad SAW, jelas redaksinya disusun oleh para sahabat yang meriwayatkan.

Kalau saja hadis qawliy ini harus disampaikan dengan lafaz sebagaimana yang disampaikan oleh Rasulullah SAW, niscaya peri-wayatan hadis bi al-ma'na ini tidak akan terjadi. Namun kenyataannya untuk pengertian yang sama terdapat hadis-hadis yang berbeda-beda redaksinya. Hal ini dapat dilihat dari contoh hadis berikut:

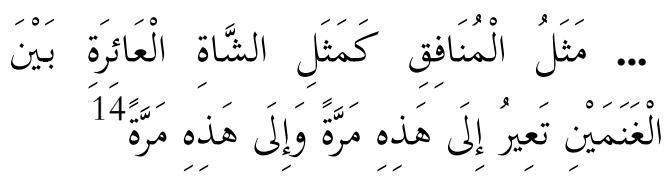

Perumpamaan orang munafik itu bagaikan seekor kambing di antara dua kambing (yang bingung untuk menentukan mana yang harus diikuti), terkadang mengikuti yang ini dan terkadang mengikuti yang itu.

Dalam riwayat lain disebutkan sebagai berikut:

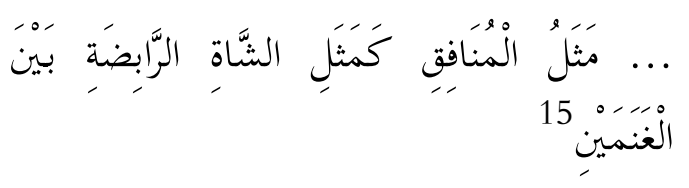

${ }^{14}$ Imam Muslim, op. cit., h. 1073

${ }^{15} \mathrm{Abu}$ 'Abd Ahmad Ibn Hanbal, Musnad Ahmad Ibn Hanbal, (Beirut: AlMakhtab al-Islamiy, 1398M), Cet. -2, juz . 2, h .32
... Perumpamaan orang munafik itu adalah seperti seekor kambing yang bingung di antara dua ekor kambing.

Penggantian kata الْغنمينَ dengan الرَّبضتين sebenarnya tidak merobah makná hadis tersebut, katakata tersebut muradif atau sinonim. Salah satu kata-kata yang tertera dalam hadis tersebut pastilah diformulasikan oleh para periwayat hadis tersebut, bukan lagi perkataan yang pernah disampaikan oleh Rasulullah SAW.

Sedangkan ke-fashahah-an hadis tersebut terletak pada lafaz Nabi Muhammad SAW bukan pada selainnya. $^{16}$

Kaedah ke-dhabith-an periwayat hadis ini berlaku kepada seluruh periwayat mulai dari sahabat, tabi' in, tabi' tabi' in, bahkan sampai kepada periwayat terakhir.

Walaupun periwayatan hadis $b i$ al-ma'na ini merupakan pembicaraan masa lampau yakni sebelum hadis Rasulullah SAW dibukukan, namun kajian tersebut sangat penting artinya dibicarakan dalam hubungannya dengan masa sekarang ini, sehingga keberadaan hadis tersebut sebagai sumber hukum sesudah Al-Quran, untuk masa sekarang dan masa yang akan datang terjamin dan terpelihara keshahihan-nya.

Periwayatan hadis bi al-ma'na ini tidak terlepas dari proses penerimaan dan penyampaian hadis.

16 Jalal al-Din 'Abd al-Rahman Ibn Abiy Bakr al-Suyuthiy, Tadrib al-Rawiy fiy Syarh Taqrib al-Nabawiy, (Beirut; Dar al-Ihya al-Sunnah al-Nabawiyyah , 1979 M), Cet .2 , h. 313 
Para ulama hanya mensyaratkan tamyiz saja untuk periwayat yang menerima hadis. Artinya anak-anak dan orang kafir sekali pun boleh menerima atau mengikuti majelis hadis. Namun ketika menyampaikan hadis, diperketat persyaratannya, yakni Islam, baligh, adil dan dhabith. ${ }^{17}$

Dalam periwayatan hadis tentang suatu topik tertentu, ditemukan lafaz yang berbeda-beda. Hal ini menunjukkan bahwa periwayatan hadis bi al-ma'na ini sudah terjadi dan tidak dapat dihindarkan. Bahkan hadis-hadis mutawatir pun kebanyakan riwayat $b i$ al-ma'na. Adapun hadis-hadis Rasulullah SAW yang mutawatir lafzhi tidak lebih dari 10 hadis. ${ }^{18}$ Namun tidak ada seorang ulama pun yang menyebutkan urutan 1-10 tentang hadis riwayat bi lafzhi ini.

Ditinjau dari pesyaratan dhabith, seakan-akan periwayatan $b i$ al-ma'na ini terjadi karena ketidakdhabith-an para periwayat, karena hal ini terjadi karena periwayat tidak ingat lafaz hadis yang pernah disampaikan Nabi Muhammad SAW. Para ulama bukan berarti tidak konsisten dengan persyaratan kesahihan hadis, khususnya tentang kriteria dhabith. Periwayatan bi al-ma'na ini adalah suatu keringanan atau rukhshah dalam periwayatan hadis, sesuai dengan kriteria-kriteria tertentu yang telah ditetapkan para ulama sebelum hadis-hadis Rasulullah SAW dibukukan secara resmi atau tadwin al-hadis yang dilakukan oleh para muhadditsin.

\footnotetext{
${ }^{17}$ Muhaammad 'Ajjaj al-Khatib, op. cit., h. 148-150

${ }^{18}$ Mahmud Aziz, op. cit., h ,19
}

Di antara kriteria yang mesti dipenuhi oleh periwayat yang meriwayatkan hadis bi al-ma'na adalah orang yang berpegang teguh pada ajaran agama Islam, mengetahui dengan pasti hadis yang disampaikannya, mengetahui hal-hal yang akan merubah makna hadis dengan berubahnya lafaz, dalam keadaan terpaksa (tidak ingat sama sekali lafaz hadis yang diucapkan Rasulullah SAW), kata-kata yang dipakai adalah sinonimnya dan mengeahui hal-hal yang akan merubah makna hadis dan hal-hal yang tidak akan merubah maknanya dengan berubahnya lafaz. ${ }^{19}$ Namun hadis-hadis tentang jawami' al-kalam tidak dibenarkan disampaikan dengan cara bi-al-ma'na. ${ }^{20}$

Jika periwayatan bi al-ma'na ini tidak diperbolehkan, mungkin saja akan menyembunyikan hukum-hukum yang telah ditetapkan Allah SWT dan Rasulullah SAW.

\section{PENUTUP}

Kebolehan periwayatan hadis $b i$ al-ma'na ini, tidak bertentangan dengan kriteria ke-dhabith-an periwayat dan tidak pula berarti merupakan indikasi bahwa ulama tidak konsisten dengan persyaratan dhabith, namun masih dalam batas-batas kedhabith-an periwayat, karena periwayat mengingat kandungan atau makna hadis tersebut.

\footnotetext{
${ }^{19}$ Muhammad ibn Ibrahim alShan'aniy, Tawdhih al-Afkar li Ma'aniy Tanqih al-Azhar,

Madinah: Maktabah al-Salafiyah, t. th.), Jilid 2, h. 372 dan Muhammad Ajjaj al-Khatib, Sunnah Qabl al-Tadwin, ( Kairo: Maktabah Wahdah, 1963), h. 132

${ }^{20}$ Shubhi Shalih, op. cit., h. 57
} 
Para ulama menetapkan bahwa makna atau maksud yang dituju oleh hadis sebagai pesan Rasulullah SAW tidak akan berubah. Setelah masa tadwin al-hadis, tidak ada lagi kegiatan periwayatan hadis, hadis-hadis

\section{REFERENSI}

Ibn Hanbal, Abu 'Abd Ahmad, Musnad Ahmad Ibn Hanbal, Beirut: Al-Makhtab al-Islamiy, $1398 \mathrm{M}$

al-Bukhariy, Abu 'Abd Allah Muhammad Ibn Ismail alBukhariy, selanjutnya disebut Imam, $\quad A l$ Jami'al-Shahih (Shahih alBukhariy), Beirut:Dar alFikr, / t. th

'Itr, Nur al-Din, Manhaj al-Naqd fiy ' Ulum al-Hadis, Damsyiq: Dar al-Fikr, 1399 H / 1979 M.

al-Khatib, Muhammad 'Ajjaj, Ushul alHadis: 'Ulumuh wa Mushthalahuh, Beirut: Dar al-Fikr, 2008

al-Khatib, Muhammad Ajjaj, Sunnah Qabl al-Tadwin, Kairo: Makatabah Wahdah, 1963

al-Naisaburiy, Imam Abu al-Husain Muslim Ibn al-Hajjaj alQusyairiy, Shahih Muslim, Beirut: Dar al-Kutub alIlmiyah, 2003

al-Shalih, Shubhi, 'Ulum al-Hadis wa Mushthalahuh, Beirut: Dar al-'Ilm li al-Malayin , 1977
Rasulullah SAW haruslah disampaikan berdasarkan kitab-kitab hadis yang telah dibukukan tersebut, sesuai dengan derajat ketinggian atau kualitas masingmasingnya.

al-Shan'aniy, Muhammad ibn Ibrahim, Tawdhih al-Afkar li Ma'aniy Tanqih al-Azhar, Madinah: Maktabah alSalafiyah, t. Th

al-Sijistaniy, Abu Daud Sulaiman Ibn al-'Asy'as, Sunan Abiy Daud, Indonesia: Maktabat al-Rihlaniy, /t. th.

al-Suyuthiy, Jalal al-Din 'Abd alRahman Ibn Abiy Bakr, Tadrib al-Rawiy fiy Syarh Taqrib al-Nabawiy, Beirut; Dar al-Ihya al-Sunnah alNabawiyyah , 1979 M.

al-Tirmidziy, Abu Isa Muhammad Ibn Isa Ibn Surah, Sunan alTirmidziy wa Huwa alJami' al-Shahih, Beirut: Dar al-Kutub al-Ilmiyah, 2006

Rahman, Fathur, Ikhtisar Mushthalah al-Hadis, Yogyakarta: PT. Al-Ma'arif, 1985.

Yunus, Mahmud, Kamus ArabIndonesia, Jakarta: Hidakarya Agung, 1990 